\title{
Arid land vegetation dynamics after a rare flooding event: influence of fire and grazing
}

\author{
M.E. Westbrooke ${ }^{a}$, S.K. Florentine ${ }^{\mathrm{a}, *}$, P. Milberg ${ }^{\mathrm{b}}$ \\ ${ }^{\mathrm{a}}$ School of Science and Engineering, Centre for Environmental Management, University of Ballarat, \\ PO Box 663, Victoria 3350, Australia \\ ${ }^{\mathrm{b}}$ Department of Biology IFM, Linköping University, SE 58183 Linköping, Sweden
}

Received 21 January 2004; received in revised form 21 June 2004; accepted 20 September 2004

\footnotetext{
${ }^{*}$ Corresponding author. Tel.: + 61353279231 ; fax: + 61353279240.

E mail address: s.florentine@ballarat.edu.au (S.K. Florentine).
} 


\section{Introduction}

Arid vegetation community structure, function, patterns of species colonization and succession are largely determined by climatic factors (Johnson et al., 1976; Aguado-Santacruz and Garcia-Moya, 1998). On an annual scale, precipitation pattern and intensity affect the floristic composition and biomass of grassland (Sala et al., 1988; Silvertown et al., 1994; Oesterheld et al., 2001). Even rainfall events involving $5 \mathrm{~mm}$ or less can play a vital role in affecting the species composition (Sala and Lauenroth, 1982, 1985; Florentine, 1999). Australian arid environments face El Niño-Southern Oscillation (ENSO) and therefore drought, fire and flood may occur at varying intervals (Flannery, 1999). ENSO events may consequently influence the vegetation on longer time scales, over 10-100 s of years, emphasizing the importance of understanding what happened in the past and the need to monitor future changes over a long term (Lunt, 2002).

Vegetation in arid ecosystems is affected by grazing and fire (Florentine, 1999; Drewa and Havstad, 2001). It is also a general belief that Australian arid zone vegetation is modified by episodic or sporadic high rainfall events and subsequent flooding (Smith and Morton, 1990). Griffin and Freidel (1985) emphasized that such events are crucial in triggering recruitment of long-lived perennials. Understanding the effect of a rare flooding event, and how its effect is moulded by other important vegetation-shaping factors like fire and grazing, is essential for management of semiarid vegetation.

In this study we evaluated the relative importance of fire, flooding and grazing on native vegetation by opportunistically placing pairs of permanent plots within vegetation that had experienced different combinations of fire and flooding. One plot in each pair was fenced to prevent grazing by vertebrate animals.

\section{Materials and method}

\subsection{Study area}

The study area is within the catchment of the ephemeral Olary Creek, where the vegetation is comprised of mallee open-scrub (Specht and Specht, 1999). Such vegetation has a sparse canopy of multi-stemmed eucalypts with lignotubers, so called mallee. Olary Creek arises in the Olary Ranges in northeast South Australia and flows south and east through Oakvale Station and across the New South Wales border into Loch Lilly Station (S33 $01^{\prime} 00^{\prime \prime}$, E141 $\left.08^{\prime} 10^{\prime \prime}\right)$. There, it splits into two channels, one of which flows due east to fill Woolcunda Lake and White Lake, and the other flows southeast into Nagaela Station (Fig. 1). The Creek flowed for the first time in many years in February 1989 (K. Weitch, Oakvale Station, pers. comm.) and again more extensively in February 1997 following up to $200 \mathrm{~mm}$ rainfall in $24 \mathrm{~h}$ (close to mean annual rainfall). This rare flooding event caused severe erosion and also formed an ephemeral lake within Nagaela Station after washing through mallee vegetation. The water level in the newly created lake was up to $2 \mathrm{~m}$ in the deepest 


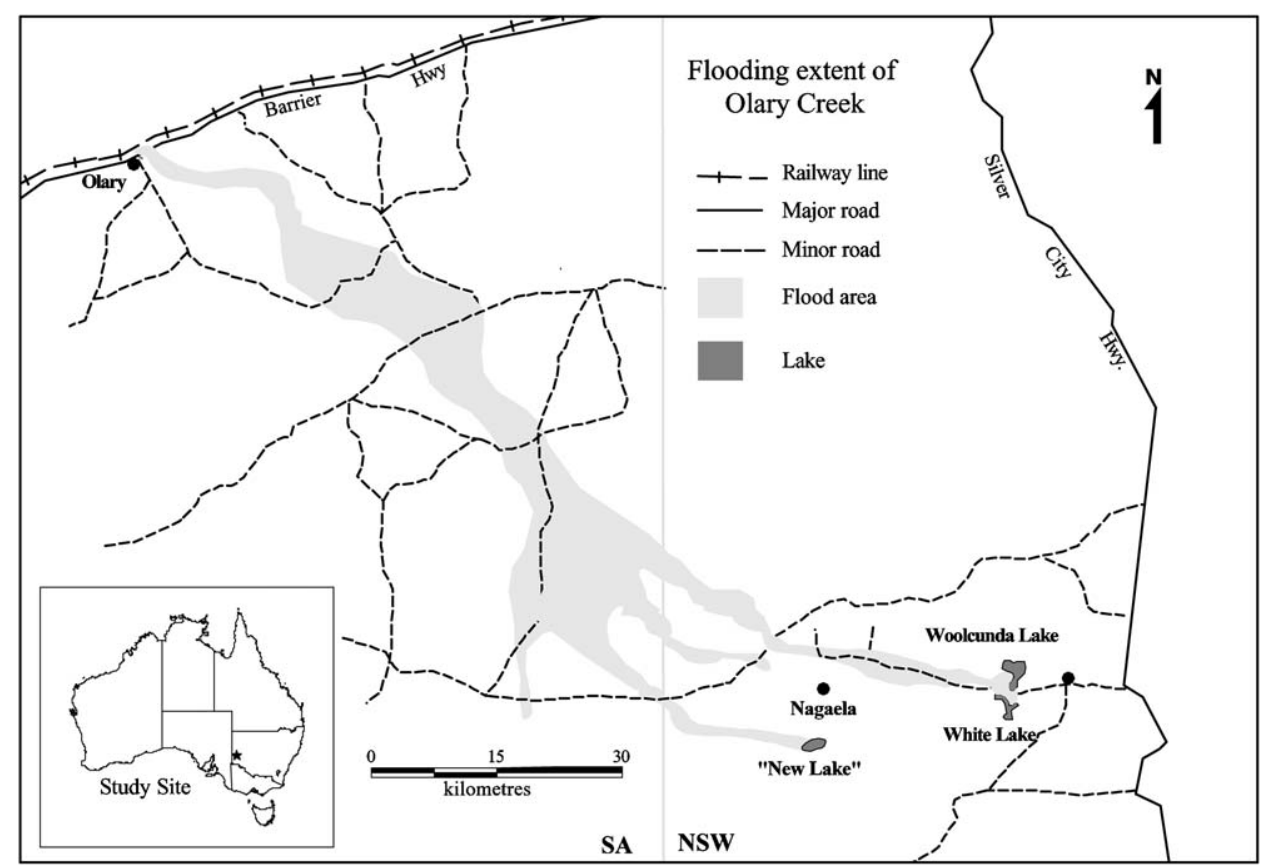

Fig. 1. Location of study site and extent of the 1997 Olary Creek flooding.

point. The floodwater-formed lake stayed for approximately a year and a half. Weston and Westbrooke (1999) suggested that the water flooded an original creek line that had not flowed to this extent for more than 100 years, allowing the drift of sand and establishment of mallee vegetation. Rainfall records and reports from Olary and Mannahill suggest four flooding events since the 1920s (Table 1). Prior to the February 1997 flooding event, part of the vegetation around Olary Creek had been burnt by natural fire. Major vertebrate herbivores in the Olary Creek catchment are kangaroo, goats and rabbits.

\subsection{Placement of permanent plots and enclosures}

To assess the relative impact of flood, fire and grazing, permanent $625 \mathrm{~m}^{2}$ $\left(25 \times 25 \mathrm{~m}^{2}\right)$ plots were established in February 1999, after the flooding (February 1997) and fire (December 1996) events. The permanently marked plots were placed in pairs in areas that had one of the following histories: (i) not flooded, not burnt; (ii) flooded, not burnt; (iii) not flooded, burnt; and (iv) flooded, burnt. One of the plots in the pair was left unfenced while the other was fenced to prevent grazing by vertebrate animals. The fence was $1.7 \mathrm{~m}$ tall, with a $150 \mathrm{~mm}$ mesh size. There were, in total, eight pairs of plots, hence, with two replicates of the different combination of flooded and burnt. 
Table 1

Monthly rainfall $(\mathrm{mm})$ and events causing flows over the Olary Creek over the past 100 years

\begin{tabular}{|c|c|c|c|c|c|}
\hline \multirow[t]{2}{*}{ Year } & \multicolumn{2}{|c|}{ Olary } & \multicolumn{2}{|c|}{ Mannahill } & \multirow[t]{2}{*}{ Effects } \\
\hline & Feb & March & Feb & March & \\
\hline 70 year average & 25 & 18 & 21 & 15 & \\
\hline 1921 & a & a & 143 & 134 & $\begin{array}{l}\text { Flooding of Olary Creek. } \\
\text { Woolcunda and White } \\
\text { Lake filled (R. Seccombe, } \\
\text { Woolcunda Station, pers. } \\
\text { comm.) }\end{array}$ \\
\hline 1950 & 152 & 107 & 74 & 87 & $\begin{array}{l}\text { Presumed flow in upper } \\
\text { sections of Olary Creek }\end{array}$ \\
\hline 1989 & 0 & 214 & 0 & 171 & $\begin{array}{l}\text { Extensive flooding along } \\
\text { Olary Creek; Woolcunda } \\
\text { lake filled (Weston and } \\
\text { Westbrooke, 1999) }\end{array}$ \\
\hline 1997 & 216 & 0 & 271 & 0 & $\begin{array}{l}\text { Extensive flooding along } \\
\text { Olary Creek; Woolcunda } \\
\text { and White Lake filled } \\
\text { (Weston and } \\
\text { Westbrooke, 1999) }\end{array}$ \\
\hline
\end{tabular}

${ }^{\mathrm{a}}$ Data not available.

\subsection{Vegetation records}

Detailed vegetation data were collected in September 1999 (2 years and 7 months after the flooding event started) and October 2002 (5 years and 8 months after the flooding event started). The objective was to monitor recovery of vegetation following different combinations of impact. In each survey, all individuals were counted and, if possible, identified to species level. Species unable to be identified in the field were collected and identified with the aid of herbarium specimens at the University of Ballarat. Data presented here did not include Eucalyptus species. During the sampling time, lack of flower buds or capsules prevented us for accurate species identification.

\subsection{Statistical analyses}

The data were analysed with both univariate and multivariate methods. It is important to note that as the plots were opportunistically allocated after the impact, $P$-values should only be used as indicators of relationships, and we put more emphasis on the relative differences between the four explanatory variables: (i) flooded vs. not flooded, (ii) burnt vs. not burnt, (iii) year (1999 and 2002), and (iv) fenced vs. not fenced vegetation.

The explanatory power of the four factors on number of species per plot was evaluated in repeated measurement split-plot ANOVAs with grazed vs. enclosed as the split-plot factor. Only those interactions involving the controlled factors (fencing and year) were considered. 
Multivariate analyses were conducted on $\log _{10}(x+1)$ transformed vegetation data using the CANOCO 4.5 software and its default options (ter Braak and Smilauer, 2002). The purpose was to explore community level responses with direct gradient analyses (McCune and Grace, 2002; Leps and Smilauer, 2003). Initial partial Detrended Correspondence Analysis, with each one of the four factors as environmental variable and the three others as covaribles, revealed that gradients in data were relatively short (length of longest gradient between 3 and 4 SD). Without covariables, however, gradients were longer (maximum of $4.0 \mathrm{SD}$ ). Therefore, we used a model based on linear assumptions, partial redundancy analysis (pRDA), to decompose the explainable variation in the data, and a model based on unimodal assumptions, canonical correspondence analysis (CCA), for a joint illustration of all factors together. The strengths of the pRDAs were evaluated in permutation tests (9999 permutations) where appropriate permutation blocks were formed to reflect the repeated measurement and split-plot design.

\section{Results}

\subsection{Number of species}

The number of species recorded in plots changed with time (Table 2): the average number per $625 \mathrm{~m}^{2}$ dropped from 11.8 (SE 2.16) in 1999 to 5.7 (0.79) in 2002. Grazed and enclosed plots also differed (Table 2): ungrazed plots had 11.2 (1.87) and grazed 6.2 (1.06).

\subsection{Decomposition of the variation in vegetation}

Flooded plots differed in species composition from non-flooded plots (Table 3). Also, there was a significant change over time in vegetation composition (Table 3). In contrast,

Table 2

ANOVA (spilt plot repeated measures) of number of species per $25 \mathrm{~m}^{2}$ in plots that had been subjected to different combinations of fire, flooding and grazing and surveyed on two occasions

\begin{tabular}{llccc}
\hline Source & d.f. & MS & $F$ & $P$ \\
\hline A. Burnt vs. not burnt & 1 & 9.03 & 0.16 & 0.7037 \\
B: Flooded vs. not flooded & 1 & 30.0 & 0.54 & 0.4955 \\
Error & 5 & 55.6 & & \\
C: Exclosed vs. grazed & 1 & 205.0 & 25.69 & 0.0039 \\
C*A & 1 & 3.8 & 0.47 & 0.5219 \\
C*B & 1 & 0.03 & 0.004 & 0.9525 \\
Error & 5 & 8.0 & & \\
D: 1999 vs. 2002 & 1 & 294.0 & 20.10 & 0.0065 \\
D $^{* A}$ & 1 & 13.8 & 0.94 & 0.3764 \\
D*B & 1 & 42.8 & 2.92 & 0.1480 \\
Error & 5 & 14.6 & & \\
\hline
\end{tabular}


Table 3

Decomposition of the explainable variation according to four different pRDA:s

\begin{tabular}{llllll}
\hline Environmental variables & $\begin{array}{l}\text { Co } \\
\text { variables }\end{array}$ & $\begin{array}{l}\text { Explained } \\
\text { variance } \\
(\%)\end{array}$ & $F$ & $P$ & $\begin{array}{l}\text { Permutation blocks } \\
\text { defined by: } \\
\text { (samples per block) }\end{array}$ \\
\hline A: Fire/no fire & B, C, D & 1.7 & 0.775 & 0.4684 & A, B \& C (4) \\
B: Flooded/not flooded & A, C, D & 14.7 & 6.789 & 0.0001 & A, C \& D (4) \\
C: $2000 / 2002$ & A, B, D & 18.9 & 9.148 & 0.0001 & D \& plot id (2) \\
D: Fenced/not fenced & A, B, C & 6.2 & 2.970 & 0.0080 & C \& plot id (2) \\
\hline
\end{tabular}

whether plots had been burnt or not seemed less important (Table 3). Plots left open to grazing by vertebrates differed significantly from fenced plots, but the amount of variation explained was small compared with flooding and time (Table 3). Hence, the dominating trends in the data were explained by flooding and a change over time (Fig. 2).

\subsection{Flooding}

Taxa that seemed to benefit most from flooding were Eragrostis spp., the exotic Nicotiana glauca (Solanaceae) and the perennial herb Pseudognaphalium luteoalbum (Asteraceae) (low ordination scores in Table 4). Species associated with non-flooded plots were Ptilotus exaltatus, Duboisia hopwoodii, Sclerolaena diacantha and Triodia scariosa ssp. scariosa (high ordination values in Table 4).

\subsection{Change over time}

The most pronounced increase over time was exhibited by the grasses Triodia scariosa ssp. scariosa and Stipa spp. (high ordination score in Table 4). Several shortlived herbs decreased, e.g. P. luteoalbum, Ptilotus exaltatus, Calandrinia eremaea and Pimelea trichostachya (low scores in Table 4).

\subsection{Grazing}

Fencing promoted most species, especially saltbush species (Chenopodiaceae) and Stipa spp. (high ordination scores in Table 4). The spinifex grass Triodia scariosa ssp. scariosa and the exotic $N$. glauca were associated with unfenced plots (low scores in Table 4).

\section{Discussion}

\subsection{Relative importance of flood, fire and grazing}

Water availability is a key factor for plant growth, regeneration and death in arid and semiarid systems. For example, recruitment of some long-lived species is 


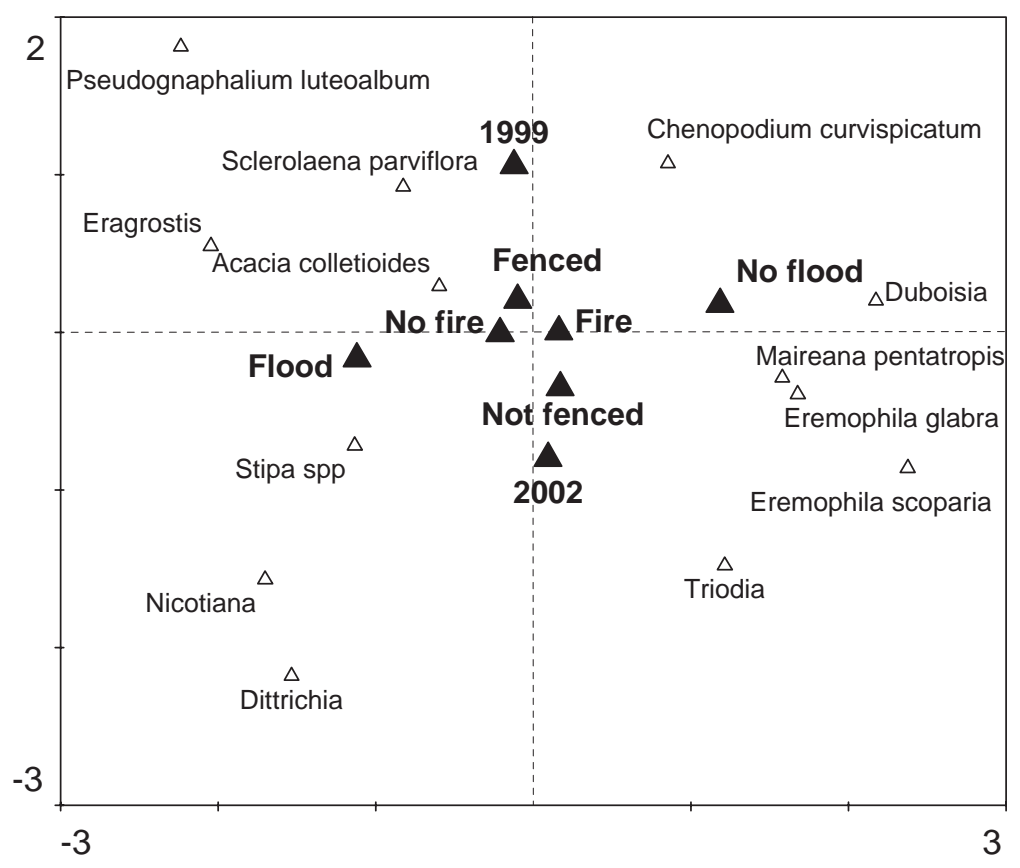

Fig. 2. Ordination graph (CCA) on vegetation in 16 plots in the Olary Creek area experiencing different combinations of flood, fire and grazing. Vegetation was sampled on two occasions (1999 and 2002). Only the most abundant of the 63 taxa recorded are illustrated; full species names in Table 4 . Eigenvalues are 0.580 and 0.495 for axis 1 and 2, respectively. Bold text and symbols indicate the explanatory variables.

probably confined to very rare occasions when soil water reservoirs are substantial enough to allow the growing taproot of seedlings to reach soil depths with reliable ground water (Henschel and Seely, 2000). Furthermore, the mortality of perennials is affected by periods of limited water availability (Herbel et al., 1972; Milton and Dean, 2000). Finally, the abundance of annuals is, to a large extent, determined by the amount of rainfall (O'Connor and Roux, 1995; Guo and Brown, 1996; Ward et al., 2000; Milton and Dean, 2000). In addition to these ways in which variation in precipitation can affect plant population dynamics, there is in some arid areas the effect of inundation. When desert soil is under water for extended time, we expect a possible wash-way effect of salt in topsoil (Zamora-Arroyo et al., 2001), additions to groundwater, as well as the death of many plants. When water eventually recedes, soil water is at a maximum, providing ample opportunity for germination and establishment of plants, especially the perennials relying on rare, large rainfall events.

Short-term dynamics in arid/semi-arid systems has been relatively well studied. As mentioned above it is well known that annuals respond strongly to interannual variation in rainfall (Bowers, 1987; Gutierrez and Whitford, 1987; Aronson and Shmida, 1992; Hobbs and Mooney, 1995; Guo and Brown, 1996; Milton and Dean, 
Table 4

Responses of the more abundant species to flooding and grazing and their change over time according to the three significant pRDAs (see Table 3)

\begin{tabular}{|c|c|c|c|c|c|c|c|c|}
\hline Species & Family & & & $\begin{array}{l}\text { Frequency } \\
(\max 32)\end{array}$ & $\begin{array}{l}\text { Total } \\
\text { abundance }\end{array}$ & $\begin{array}{l}\text { Ordination } \\
\text { score } \\
\text { flooded }^{\mathrm{a}}\end{array}$ & $\begin{array}{l}\text { Ordination } \\
\text { score } \\
\text { fenced }^{\mathrm{b}}\end{array}$ & $\begin{array}{l}\text { Ordination } \\
\text { score year }^{\mathrm{c}}\end{array}$ \\
\hline Acacia colletioides Benth. & Mimosaceae & Shrub & Perennial & 9 & 13 & 0.154 & 0.365 & 0.048 \\
\hline Calandrinia eremaea Ewart & Portulacaceae & Herb & Annual & 7 & 12 & 0.125 & 0.022 & 0.497 \\
\hline $\begin{array}{l}\text { Chenopodium curvispicatum } \\
\text { Paul G. Wilson }\end{array}$ & Chenopodiaceae & Shrub & Perennial & 8 & 33 & 0.202 & 0.273 & 0.079 \\
\hline $\begin{array}{l}\text { Chenopodium desertorum } \\
\text { (J.M. Black) J.M. Black }\end{array}$ & Chenopodiaceae & Shrub & Perennial & 6 & 14 & 0.046 & 0.325 & 0.139 \\
\hline $\begin{array}{l}\text { Duboisia hopwoodii (F. Muell.) } \\
\text { F. Muell. }\end{array}$ & Solanaceae & Shrub & Perennial & 7 & 20 & 0.464 & 0.012 & 0.050 \\
\hline Eragrostis spp. & Poaceae & Grass & Annual & 11 & 56 & 0.646 & 0.063 & 0.205 \\
\hline $\begin{array}{l}\text { Eremophila glabra (R.Br.) } \\
\text { Ostenf. }\end{array}$ & Myoporaceae & Shrub & Perennial & 8 & 40 & 0.355 & 0.167 & 0.236 \\
\hline $\begin{array}{l}\text { Maireana pentatropis (Tate) } \\
\text { Paul G. Wilson }\end{array}$ & Chenopodiaceae & Shrub & Perennial & 7 & 31 & 0.336 & 0.336 & 0.243 \\
\hline Nicotiana glauca Graham $^{\mathrm{d}}$ & Solanaceae & Shrub & Perennial & 9 & 111 & 0.539 & 0.112 & 0.344 \\
\hline Pimelea trichostachya Lindl. & Thymelaeaceae & Herb & Annual & 7 & 7 & 0.227 & 0.076 & 0.529 \\
\hline $\begin{array}{l}\text { Pseudognaphalium luteoalbum } \\
\text { (L.) Hilliard \& B.L. Burtt }\end{array}$ & Asteraceae & Herb & Perennial & 8 & 17 & 0.529 & 0.007 & 0.529 \\
\hline Ptilotus exaltatus Nees & Amaranthaceae & Herb & Annual & 7 & 9 & 0.500 & 0.000 & 0.500 \\
\hline $\begin{array}{l}\text { Sclerolaena parviflora (R.H. } \\
\text { Anderson) A.J. Scott }\end{array}$ & Chenopodiaceae & Herb & Perennial & 14 & 99 & 0.207 & 0.207 & 0.189 \\
\hline $\begin{array}{l}\text { Sclerolaena diacantha (Nees) } \\
\text { Benth. }\end{array}$ & Chenopodiaceae & Shrub & Perennial & 7 & 16 & 0.429 & 0.248 & 0.024 \\
\hline Stipa spp. & Poaceae & Grass & Perennial & 22 & 12110 & 0.433 & 0.380 & 0.372 \\
\hline $\begin{array}{l}\text { Triodia scariosa N.T. Burb. ssp. } \\
\text { Scariosa }\end{array}$ & Poaceae & Grass & Perennial & 23 & 2583 & 0.388 & 0.156 & 0.723 \\
\hline
\end{tabular}

${ }^{\text {a }}$ High ordination score: most abundant in non flooded plots.

${ }^{\mathrm{b}}$ High ordination score: most abundant in fenced plots.

${ }^{\mathrm{c}}$ High ordination score: most abundant on the second survey.

d Exotic. 
2000). Furthermore, the effect of grazing and fire has been studied (Waser and Price, 1981; Kelt and Valone, 1995; Valone and Kelt, 1999; Ward et al., 2000; Drewa and Havstad, 2001). However, the effects of very rare events, are difficult to observe and most often have to be inferred from indirect evidence (Henschel and Seely, 2000). Therefore, to evaluate the relative importance of the major factors involved in shaping vegetation in arid/semiarid environments is a difficult task. In the present study, we retrieved data after a partly burnt area had been partly flooded. Our interpretation of the data is that flooding was the most important factor for vegetation composition while fire and grazing were of much smaller importance (Table 3). It is important to note that there are potential confounding factors that might have inflated the explanatory power of "flooding". For example, although the study area is a flat landscape, flooded plots were inevitably at lower altitude. It is also worth noting that our design meant a higher power in detecting grazing effects than that of fire or flooding (paired grazed and ungrazed plots contain substantially less spatial variation than that of opportunistically placed plots spaced over a much larger area).

To put the present study into the appropriate context within the theories of water availability effect on vegetation, we need to consider that the rainfall in 1997 in itself would have meant much more water than received in a normal year. Hence, considering the interannual variation in rainfall, 1997 and the following year are likely to have been unusually good for both plant growth and regeneration and with low mortality. The flooding therefore is likely to have added an extra effect. The species that seemed to benefit most from flooding were Erogrostis spp., P. luteoalbum and the exotic $N$. glauca while those species associated with non-flooded plots were most notably Ptilotus exaltatus, Sclerolaena diacantha and Triodia scariosa.

\subsection{Change over time}

With only two points in time it is, of course, not possible to separate fluctuations from directional trends. Despite this, we would like to infer the following sequence of events. The 1997 rainfall, and the flooding, is likely to have caused a flush in regeneration from seed and surviving root parts, once the water receded. As annual rain inputs went back to normal, we would expect to encounter drought-caused mortality among the large number of recruits. As we have no assessment of vegetation before the impact, we could not monitor the expected "flush-effect" of the 1997 rain. But we did observe a decrease in species richness, most likely caused by such mortality. Similar effects have been observed in other fire prone vegetation communities (Auld and O'Connell, 1991; Friedel et al., 1993; Pickup et al., 2003).

\subsection{Grazing}

Grazing explained parts of the variation in vegetation data (Table 3). Only two species, the exotic $N$. glauca and Triodia scariosa clearly benefited from grazing while the majority were negatively affected. Trioida is a genus of so called spinifex grasses that dominate in arid parts of Australia and which are prickly and avoided by 
herbivores (Griffin, 1990). N. glauca has deterring chemicals and can be highly toxic to humans (Mizrachi et al., 2000) and animals (Panter et al., 2000).

A detailed study of $N$. glauca in the area confirms that the invasion of this species was greatly facilitated by flooding, especially in combination with grazing (Florentine and Westbrooke, submitted). Moreover, this study showed the legacy of the flooding event by the presence of $N$. glauca in the seed bank of flooded areas only. Another flooding may help N. glauca spread further with seeds along the catchment and extend its distribution. Thus flooding can contribute to expanding the distribution of environmental weeds (Cellot et al., 1998).

\section{Conclusions}

Although much has been published on the effects of fire and grazing on native vegetation and species composition, our study highlights the effects of episodic flooding events on arid landscape vegetation. Our study clearly showed that (i) the unusual flooding event affected post-flood vegetation, (ii) plots left open to grazing by vertebrates differed from fenced plots, but the amount of variation explained was small compared with flooding and the change over time, (iii) species that seemed to benefit most from flooding were P. luteoalbum, Eragrostis spp. and the exotic $N$. glauca.

\section{Acknowledgements}

We thank Marion O'Keefe for field assistance and preparation of figures. The University of Ballarat provided financial support for this study. An anonymous referee and Dr. M. Oesterheld provided constructive comments.

\section{References}

Aguado Santacruz, G.A., Garcia Moya, E., 1998. Environmental factors and community dynamics at the southernmost part of the North American Graminetum. I. On the contribution of climatic factors to temporal variation in species composition. Plant Ecology 135, 1329.

Aronson, J., Shmida, A., 1992. Plant species diversity along a Mediterranean desert gradient and its correlation with interannual rainfall fluctuations. Journal of Arid Environments 23, 235247.

Auld, T.D., O’Connell, M.A., 1991. Predicting patterns of post fire germination in 35 eastern Fabaceae. Australian Journal of Ecology 16, 5570.

Bowers, M.A., 1987. Precipitation and the relative abundances of desert winter annuals: a 6 year study in the northern Mohave desert. Journal of Arid Environments 12, 141150.

Cellot, B., Mouillot, F., Henry, C.P., 1998. Flood drift and propagule bank of aquatic macrophytes in a riverine wetlands. Journal of Vegetation Science 9, 631640.

Drewa, P.B., Havstad, K.M., 2001. Effects of fire, grazing and the presence of shrubs on Chihuahuan desert grasslands. Journal of Arid Environments 48, 429443.

Flannery, T.F., 1999. Twenty million years of rangelands evolution in Australia and North America. In: Eldridge D., Freudenberger, D. (Eds.), People and rangelands building the future. Proceedings of the VIth International Rangeland Congress, pp. 24. 
Florentine S.K., Westbrooke, M.E., submitted. Invasion of the noxious weed Nicotiana glauca R. Graham after an episodic flooding event in the arid zone of Australia. Journal of Arid Environments, in press.

Florentine, S.K., 1999. Ecology of Eucalyptus victrix in grassland in the floodplain of the Fortescue River. Ph.D. Thesis, Curtin University of Technology, WA, Australia.

Friedel, M.H., Pickup, G., Nelson, D.J., 1993. The interpretation of vegetation change in a spatially and temporally diverse arid Australian landscape. Journal of Arid Environments 24, 241260.

Griffin, G.F., Freidel, M.H., 1985. Discontinuous change in central Australia: some implications of major ecological events for land management. Journal of Arid Environments 9, 6380.

Griffin, G.F., 1990. Characteristics of three spinifex alliances in Central Australia. Journal of Vegetation Science 4, 437444.

Guo, Q.F., Brown, J.H., 1996. Temporal fluctuations and experimental effects in desert communities. Oecologia 107, 568577.

Gutierrez, J.R., Whitford, W.G., 1987. Responses of Chihuahuan Desert herbaceous annuals to rainfall augmentation. Journal of Arid Environments 12, 127139.

Henschel, J.R., Seely, M.K., 2000. Long term growth patterns of Welwitschia mirabilis, a long lived plant of the Namib Desert (including a bibliography). Plant Ecology 150, 726.

Herbel, C.H., Ares, F.N., Wright, R.A., 1972. Drought effects on a semidesert grassland range. Ecology 53, 10841093.

Hobbs, R.J., Mooney, H.A., 1995. Spatial and temporal variability in California annual grassland results from a long term study. Journal of Vegetation Science 6, 4356.

Johnson, W.C., Burgess, R.L., Keammerer, W.R., 1976. Forest recovery vegetation and environment on the Missouri River floodplain in North Dakota. Ecological Monographs 46, 5984.

Kelt, D.A., Valone, T.J., 1995. Effects of grazing on the abundance and diversity of annual plants in Chihuahuan desert scrub habitat. Oecologia 103, 191195.

Leps, J., Smilauer, P., 2003. Multivariate analysis of ecological data using CANOCO. Cambridge University Press, Cambridge.

Lunt, I.D., 2002. Grazed, burnt and cleared: how ecologists have studied century scale vegetation changes in Australia. Australian Journal of Botany 50, 391407.

McCune, B., Grace, J.B., 2002. Analysis of ecological communities. MjM Sofware Design, Gleneden Beach, Oregon.

Milton, S.J., Dean, W.R.J., 2000. Disturbance, drought and dynamics of desert dune grassland, South Africa. Plant Ecology 150, 3751.

Mizrachi, N., Levy, S., Goren, Z., 2000. Fatal poising from Nicotiana glauca leaves: identification of anabasine by gas chromatography/mass spectrometry. Journal of Forensic Science 45, 736741.

O'Connor, T.G., Roux, P.W., 1995. Vegetation changes (1949 71) in a semi arid, grassy dwarf shrubland in the Karoo, South Africa: influence of rainfall variability and grazing by sheep. Journal of Applied Ecology 32, 612626.

Oesterheld, M., Loreti, J., Semmartin, M., Sala, O.E., 2001. Inter annual variation in primary production of a semi arid grassland related to previous year production. Journal of Vegetation Science 12, 137142.

Panter, K.E., Weinzweig, J., Gardner, D.R., Stegelmeier, B.L., James, L.F., 2000. Comparison of cleft palate induction by Nicotiana glauca in goats and sheep. Teratology 61, 203210.

Pickup, M., Mcdougall, K.L., Whelan, T.J., 2003. Fire and flood: Soil stored seed bank and germination ecology in the endangered Carrington Falls grevillea (Grevillea rivularis, Proteaceae). Austral Ecology $28,128136$.

Sala, O.E., Lauenroth, W.K., 1982. Small rainfall events: an ecological effects in semiarid regions. South African Journal of Science 53, 301304.

Sala, O.E., Lauenroth, W.K., 1985. Root profiles and the ecological effects of light rainshowers in arid and semiarid regions. The American Midland Naturalist 114, 406408.

Sala, O.E., Parton, W.J., Joyce, L.A., Lauenroth, W.K., 1988. Primary production of the central grassland region of the United States. Ecology 69, 4045. 
Silvertown., J., Dodd, M.E., McConway, K., Potts, J., Crawley, M., 1994. Rainfall, biomass variation, and community composition in the park grass experiment. Ecology 75, 2430-2437.

Smith, S.D.M., Morton, S.R., 1990. A framework for the ecology of arid Australia. Journal of Arid Environments 18, 255-278.

Specht, R.L., Specht, A., 1999. Australian plant communities. Dynamics of structure, growth and biodiversity. Oxford University Press, Oxford.

ter Braak, C.J.F., Smilauer, P., 2002. CANOCO Reference manual and user's guide to Canoco for Windows: Software for Canonical Community Ordination (version 4.5). Microcomputer Power, Ithaca, New York, USA.

Valone, T.J., Kelt, D.A., 1999. Fire and grazing in a shrub-invaded arid grassland community: independent or interactive ecological effects. Journal of Arid Environments 42, 15-28.

Ward, D., Saltz, D., Olsvid-Whittaker, L., 2000. Distinguishing signal from noise: long-term studies of vegetation in Makhtesh Ramon erosion cirque, Negev Desert, Israel. Plant Ecology 150, $27-36$.

Waser, N.M., Price, M.V., 1981. Effects of grazing on diversity of annual plants in the Sonoran Desert. Oecologia 50, 407-411.

Weston, M., Westbrooke, M.E., 1999. The role of episodic events in moulding the vegetation of a part of western New South Wales. In: People and rangelands-Building the Future, Proceedings of the VIth International Rangeland Congress, pp. 255-256.

Zamora-Arroyo, F., Nagler, P.L., Briggs, M., Radtke, D., Rodriquez, H., Garcia, J., Valdes, C., Huete, A., Glenn, E.P., 2001. Regeneration of native trees in response to flood release from the United States into the delta of the Colorado River, Mexico. Journal of Arid Environments 49, 49-64. 